Jahrbuch für Geschichte Lateinamerikas

Anuario de Historia de América Latina

$57|2020| 87-121$

\title{
Miguel Rodrigues Lourenço
}

Centro de Humanidades

Universidade NOVA de Lisboa

Inquisition and Empire: The Holy Office of Goa between Padroado and Propaganda Fide (1666-1681)
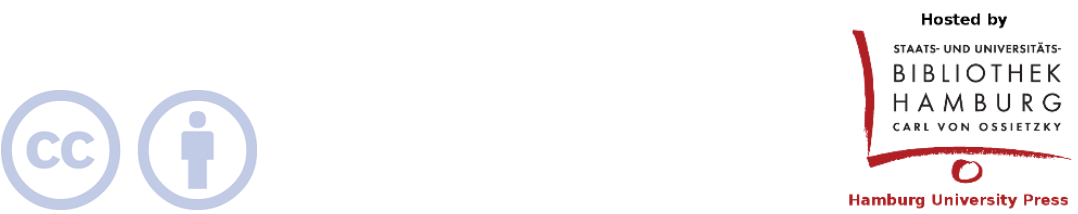

Except where otherwise noted, this article is licensed under a Creative Commons Attribution 4.0 International license (CC BY 4.0)

https://doi.org/10.15460/jbla.57.191 


\title{
Inquisition and Empire: The Holy Office of Goa between Padroado and Propaganda Fide (1666-1681)
}

\author{
Miguel Rodrigues Lourenço ${ }^{1}$
}

Abstract. - During the dispute between Portugal and the Holy See over the rights of Patronage (Padroado real) in Asia, the Inquisition played a secondary role in the legal allegations of the Crown. In the local context of the controversies with the apostolic vicars sent by the Congregation de Propaganda Fide, priests and missionaries of the Portuguese Padroado saw the Holy Office as an instrument to defend the rights of the Crown, arresting and excommunicating on behalf of the tribunal. Imperial agents in the Estado da Índia envisioned the Inquisition as an instrument for claiming jurisdictional rights over territory, while they also faced conflicts with the inquisitors.

Keywords: Inquisition, Propaganda Fide, Padroado, Jurisdiction, Empire.

Resumen. - Durante la disputa entre Portugal y la Santa Sede sobre los derechos del Patronato (Padroado real) en Asia, la Inquisición desempeñó un papel secundario en las alegaciones legales de la Corona. Sin embargo, en el contexto local de las controversias con los vicarios apostólicos enviados por la Congregación de Propaganda Fide, los sacerdotes y misioneros del Padroado portugués vieron en el Santo Oficio un instrumento para defender los derechos de la Corona, deteniendo y excomulgando en nombre del tribunal. En este artículo se analizan las expectativas de los agentes imperiales en cuanto a la posibilidad de que la Inquisición pudiera ser un instrumento para reclamar derechos jurisdiccionales sobre el territorio a la Corona y las

\footnotetext{
1 Researcher at CHAM, FCSH, Universidade NOVA de Lisboa, at the Centro de Estudos de História Religiosa (UCP) and the Cátedra de Estudos Sefarditas Alberto Beneviste (FLUL). This article is part of the project Religion, Ecclesiastical Administration, and Justice in the Portuguese Seaborne Empire (1514-1750) ReligionAJE, PTDC/HAR-HIS/28719/2017, which is sponsored by the Portuguese Foundation for Science and Technology - FCT and H2020.
} 
contrariedades que experimentaron ante la gestión de los acontecimientos por parte de los inquisidores.

Palabras clave: Inquisición, Propaganda Fide, Padroado, jurisdicción, imperio.

Over the years, historians have analyzed the Goa Inquisition from a predominantly political point of view. They recognized that the tribunal played a significant role in maintaining a social order based on fidelity to the monarch and the faith. Despite their differing theoretical frameworks, scholars agree that Inquisition and Empire shared a common trajectory, where the action of the former was objectively reflected in the consolidation of the latter. Notions such as "political guarantee" by J. Borges de Macedo in 1995 or "inquisitorial colonialism" by G. Marcocci in 2011 indicate a common understanding that there was a facet of Portuguese power in Asia that relied to an extent on vigilance and punishment for territorial consolidation.

In this article, we analyze the political functions of the Holy Office in an imperial context, namely the extent to which it was perceived as a means to enforce jurisdiction over territories. In the 17th century, the legal controversies between Portugal and the Holy See regarding the creation of ecclesiastical structures independent from the Portuguese dioceses posed the problem of the Crown's jurisdiction over territories where the King did not have temporal dominion in a very pressing way. During the disputes with the apostolic vicars sent by the Congregation of Propaganda Fide to Southeast Asia, Portuguese ecclesiastical authorities resorted to the inquisitorial forum to defend the Crown's rights of Patronage over the missions and local Catholic communities. We will address the way the Inquisition of Goa took part in the controversy over the Portuguese Crown's rights of Patronage (Padroado real) that unfolded after the arrival of Pierre Lambert de la Motte in Siam as apostolic vicar of the Congregation of Propaganda Fide in 1662. We will focus on the period from the first clash between Lambert de la Motte and a representative of inquisitorial jurisdiction in 1666 and the creation of the Junta das Missões in Goa (1681). Our aim is to evaluate three levels of the Inquisition's participation in the controversy: firstly, the actions of the representatives of the inquisitorial or the bishops' jurisdiction; secondly, the management of the events by the inquisitors in Goa; and finally, the role of the Holy 
Office in the legal allegations of the Crown in the dispute over its rights of Patronage.

\section{The Holy Office and the Crown's Jurisdiction over Territories}

Since the late 1980s and the 1990s, the scholarship on Portuguese expansion strove to further the knowledge on the Portuguese administration in Asia and East Africa, referred to as Estado da Índia. Scholars paid increased attention to the agents who furthered its cohesion (Portuguese or European, mestizo or local, Catholic, Muslim or Gentile, merchants, soldiers or missionaries) and to the different forms of solidarity that supported it beyond the classical institutional links. The study of the ecclesiastical structures was not neglected as scholars underlined the role of the new dioceses and the missionaries in linking the territories to the Portuguese Crown. ${ }^{2}$

Historians, however, have largely disregarded the Inquisition of Goa, created in 1560 and its contribution to consolidating the colonial status quo. $^{3}$ Anant Kakba Priolkar proposed in 1961 that the Holy Office should be analyzed in the context of the broader and more systematic Portuguese policy of religious persecution to convert local populations to Christianity. Priolkar recognized a historical meaning in the

\footnotetext{
2 See, in particular: Francisco Bethencourt, "A Igreja”: Francisco Bethencourt / Kirti Chaudhuri (eds.), História da Expansão Portuguesa, [s.l.]: Círculo de Leitores, 1998, vol. 1, pp. 369-386; Caio Boschi, "As missões na África e no Oriente": Francisco Bethencourt / Kirti Chaudhuri (eds.), História da Expansão Portuguesa, [s.l.]: Círculo de Leitores, 1998, vol. 2, pp. 403-418; João Paulo Oliveira e Costa, "A diáspora missionária": Carlos Moreira Azevedo (ed.), História religiosa de Portugal, [s.l.]: Círculo de Leitores, 2000, vol. 2, pp. 255-311; also, José Pedro Paiva, Os bispos de Portugal e do Império. 1495-1777, Coimbra: Imprensa da Universidade, 2006; on the role of missionaries as agents of a territorialization of conversions and therefore of transformation of the colonial spaces of Goa, Salcete and Bardez, see Ângela Barreto Xavier, A invenção de Goa. Poder imperial e conversões culturais nos séculos XVI e XVII, Lisbon: Instituto de Ciências Sociais, 2008, pp. 113-118.

3 On the establishment of the Inquisition in Goa read Ana Cannas da Cunha, A Inquisição no Estado da Índia. Origens (1539-1560), Lisbon: Arquivos Nacionais / Torre do Tombo, 1995 and José Pedro Paiva, "The Inquisition Tribunal in Goa. Why and for What Purpose?": Journal of Early Modern History, 21 (2017), pp. 565593.
} 
tribunal's activity that he linked to the Christianization of the Portuguese domains. He furthermore ascribed a major role to the Inquisition in the subsequent conception and enforcement of religious policies in Goa through the exercise of pressure over secular authorities. ${ }^{4}$

The slow progress of studies on the Goa Inquisition did not lead to a closer dialogue with Priolkar's work. However, the idea of a tribunal also committed to conversion prevailed in the works that showed a preference for a more global or imperial reading of the subject. Francisco Bethencourt argued that the Goa tribunal displayed an impressive rhythm considering the extent and territorial discontinuity of its district. This peculiarity should in his opinion be considered against "the model of Christianization followed in the Portuguese empire in the East and the role of the Inquisition in those peripheries". 5 The Holy Office was a "political guarantee" of this Christianization, as Jorge Borges de Macedo wrote in 1995, reflecting on the reasons for its transfer to such a porous and fragmented space. ${ }^{6}$ Another eminently political reading of the role of the Holy Office in the Estado da Índia led Glenn J. Ames to emphasize the influence of the inquisitors in implementing political strategies during the second half of the 17th century. ${ }^{7}$ Ângela Barreto Xavier addressed the choice for creating a branch of the Inquisition in Goa, considering it as part of the process of political sophistication of the Estado da Índia, that replicated institutional structures existing in Portugal in order to achieve the cultural and religious transformation of the populations under Portuguese rule. In her analysis the Holy Office was not overlooked in its fundamental role as a resource for eradicating the idolatry of the converted populations. ${ }^{8}$ In 2011, Giuseppe Marcocci regretted that

4 Anant Kakba Priolkar, The Goa Inquisition. Being a Quartercentenary Commemoration Study of the Inquisition in India, Panaji: Prabhakar Bhide, 2008 (1961), p. 58 and chapters 6, 8 and 10.

5 Francisco Bethencourt, História das inquisições. Portugal, Espanha e Itália, Lisbon: Círculo de Leitores, 1994, pp. 273-274.

6 Jorge Borges de Macedo, "Uma opinião em forma de prefácio”: Cunha, A Inquisição, p. 13.

7 Gleen J. Ames, Renascent Empire? The House of Braganza and the Quest for Stability in Portuguese Monsoon Asia. Ca. 1640-1683, Amsterdam: Amsterdam University Press, 2000, pp. 64, 76-91.

8 Barreto Xavier, A invenção de Goa, p. 326. See, also, pp. 63-74. 
scholarship still neglected the ties that bound Inquisition and conquest, seeking to respond to this void through a global reading of the Inquisition in extra-European territories. ${ }^{9}$ His understanding of the convergence between inquisitors and missionaries on the scale of the empire was best observed in Goa, where "[m]issions and Inquisition thus became the two faces, not always easy to distinguish, of a policy founded on the conversion of local populations".10 In recent years, Christianization from the point of view of the confessionalization 11 policies of the Kings of Portugal formed the basis on which José Pedro Paiva devised a broad questionnaire to analyze the establishment of the Inquisition in Goa. ${ }^{12}$

In these studies, historiography has paid more attention to the territorial center of power in the Indian Ocean (Goa and the "Old Conquests") or to its closer territorial domains (Northern Province). However, the Crown of Portugal advanced its interests in Asia and East Africa-a part of the Estado da Índia at the time-in diverse territories, not always benefiting from having full sovereignty. In an already classic paper, Luís Filipe Thomaz authored an important effort to define the institutional characteristics of the Estado da Índia. Moving away from the effective domination of territories and populations, Thomaz proposed a "network" of a "communication system" to better define

\footnotetext{
${ }^{9}$ Giuseppe Marcocci, "A fé de um império. A Inquisição no mundo português de quinhentos": Revista de História, 164 (2011), p. 74.

10 Marcocci, "A fé de um império", p. 82; Giuseppe Marcocci, A Consciência de um império. Portugal e o seu mundo (sécs. XV-XVII), Coimbra: Imprensa da Universidade, 2014, p. 400.

11 The concept of "confessionalization" (Konfessionalisierung) was employed by Wolfgang Reinhard and Heinz Schilling to frame the ideological processes in the formation of homogenous confessional groups and the extension of such principles to societies through mechanisms of discipline and vigilance. See Heinz Schilling, "Reformation und Konfessionalisierung in Deutschland und die neuere deutsche Geschichte": Gegenwartskunde, Sonderheft 5 (1988), pp. 11-29; Wolfgang Reinhard, "Confessionalizzazione forzata? Prolegomeni ad una teoria dell'età confessionale": Annali dell'Istituto storico italo-germanico in Trento, 8 (1982), pp. 13-37; Federico Palomo, “'Disciplina christiana'. Apuntes historiográficos en torno a la disciplina y el disciplinamiento social como categorías de la historia religiosa de la alta edad moderna": Cuadernos de Historia Moderna, 18 (1997), pp. 119-136.

12 Paiva, “The Inquisition Tribunal”, pp. 565-593, esp. 579-583.
} 
what was conventionally called the "Portuguese Seaborne Empire"13 or the "Portuguese Empire in Asia".14 The author did not emphasize the territorial discontinuity or the reduced spatiality of the Estado da Índia-limited in many cases to the territory of a fortress and its immediate hinterland-but its rather heterogeneous reality, marked by different forms of occupation or presence in the territories, from full and shared sovereignty to a tolerated or agreed to presence. ${ }^{15}$ Therefore, the Estado da Índia, in Thomaz's definition, would be

"not a geographically well-defined space, but the set of territories, establishments, goods, people and interests administered, managed or tutored by the Portuguese Crown in the Indian Ocean and adjacent seas or in the riverside territories, from the Cape of Good Hope to Japan".16

The peripheries of the empire were spaces of agreed intersections, negotiated and continuously adjusted between informality and institutionalization, a reality that the economic and material constraints of the Portuguese Crown could not overcome. In Southeast Asia and East Asia, the lack of full sovereignty was but a side of the peculiarities of the Portuguese presence in the region. Imperial agents, for example in the Philippines, experienced constraints of a different order that derived from the particular political solution found by Philip II (King of Portugal from 1581 to 1598) to manage the incorporation of the Crown of Portugal in its domains: the respect for the integrity and autonomy of the Iberian empires, that prevented any form of jurisdictional overlapping between the territories belonging to different Crowns. The contradiction of a compromise between a political configuration at the limit of its military capabilities - the Estado da Índia-and another at the peak of its strength-the government of the Philippines-was notorious to various players on both sides. This generated resentment at the restrictions imposed on the participation of the subjects of the

${ }^{13}$ Charles R. Boxer, The Portuguese Seaborne Empire. 1415-1825, New York: Alfred A. Knopf, 1969.

14 Sanjay Subrahmanyam, The Portuguese Empire in Asia 1500-1700, London: Longman Group UK Limited, 1993.

15 Luís Filipe F. R. Thomaz, "Estrutura política e administrativa do Estado da Índia no século XVI": Luíz Filipe F. R. Thomaz, De Ceuta a Timor, Miraflores: Difel, 1998 (2nd edition), p. 207. The paper was first published in 1985 and later incorporated in this book.

16 Thomaz, "Estrutura política e administrativa", p. 208. 
Crown of Castile in commerce or in the missions of territories bound to the Crown of Portugal. It was certainly the will to get around these impediments that contributed to the fact that some of the participants began to look at the Holy Office and the jurisdictional links established between tribunal and community-and thus with territory - as a way of legitimizing access to certain regions from the Philippine side.

The behavior of the religious orders in the Philippines bore this out. In 1601, Bernardo de Santa Catalina, a Dominican friar, alerted the Inquisition of Mexico to the fact that the Holy Office lacked a commissary in Japan. ${ }^{17}$ For this reason, he suggested that the inquisitors should appoint a commissary to the islands. The suggestion was far from being arbitrary. The Dominicans of the Philippines then considered establishing a mission in Japan-which would take place in 1602 on Satsuma-despite the establishment of a diocese in Japan assigned to the Portuguese Patronage (1588) and papal directives that mendicant missionaries should enter Japan via Portuguese routes (1600). Bernardo de Santa Catalina, himself a commissary of the Holy Office, sought to open up a space of legitimacy from which his orderor any other in Manila-could benefit to access the archipelago.

A similar attitude can be seen in Ternate (in the islands of Maluku), in 1643, only one year after the news of the Portuguese Crown's rebellion against the Habsburgs (1640) became known in the Philippines. On that date, governor Sebastián Hurtado de Corcuera ordered that the Jesuit Manuel Carvalho, rector of the Jesuit college in Ternate and commissary of the Goa Inquisition, should come to Manila. On receiving the governor's instruction to send a Spanish Jesuit to Ternate, the provincial of the Philippines of the Society of Jesus, Francisco Colín, asked the Inquisition of Mexico to appoint a commissary for the island. Manuel Carvalho objected to the idea of sending Spanish Jesuits to Ternate, claiming that it was a way of annexing the island and mission of Maluku to the province of the Philippines. ${ }^{18}$

17 Letter of Fr. Bernardo de Santa Catalina, OP, Commissary of the Holy Office in Manila, to the Inquisition of Mexico, 12 July 1601, Manila. Archivo General de la Nación [AGN], Inquisición, vol. 263, f. 66.

18 Letter from Fr. Francisco Colín, SJ, Provincial of the Phillippines, to the Inquisition of Mexico, of July 18, 1642, in Manila. AGN, Inquisición, vol. 416, fls. 18v-19; Letter from Fr. Manuel Carvalho, SJ, of August 4, 1643, in Manila. Archivum Romanum 
Something similar happened in Macau in 1642, when captain Claudio Verastigui arrived to ensure the city's allegiance to Philip IV (III as King of Portugal, 1621-1665) and prevent it from opting for the newly proclaimed monarch, John IV (1640-1656). In November of that year, rumors circulated in Macau that a new commissary of the Holy Office, loyal to the Spanish Habsburgs, was appointed from the Philippines. This meant that the Inquisition was effectively perceived as a criterion for jurisdictional assertion over a given territory or community. ${ }^{19}$

\section{Conflicts and Contradictions: The Inquisition in the Face of the Missionary Projection of the Congregation of Propaganda Fide}

Even if ecclesiastical agents residing in East and Southeast Asia shared this awareness, that does not mean that the institutional link to the Holy Office was primarily invoked as a positive value of sovereignty in matters of jurisdictional claim. This was visible during the second half of the 17th century in the context of the long jurisdictional dispute between the Crown of Portugal and the Holy See regarding the establishment of missions that would be autonomous from the Portuguese episcopate in Southeast Asia and East Asia. ${ }^{20}$ Despite a series of clashes between the apostolic vicars sent by the Propaganda Fide and the Holy Office of Goa (1666-1670), the inquisitors maintained positions contrary to those of its agents who claimed the defense of the rights of Patronage by resorting to inquisitorial jurisdiction.

Societatis Iesu [ARSI], Goana 9-1, f. 161v. On this matter, see Miguel Rodrigues Lourenço, “¿Gestión de la distancia o reajuste de jurisdicciones? La propuesta de fundación de un tribunal del Santo Oficio en las Filipinas por el jesuita Francisco Velho (1658)": Histórica, 43: 2 (2019), pp. 17-58, en línea: https://doi.org/10.18800/historica.201902.001 [20-11-2020].

19 "'Informação de uma controvérsia e desinquietação que se moveu em Macau, cidade dos portugueses no Reino da China' de Novembro de 1642": Miguel Rodrigues Lourenço, Macau e a inquisição nos séculos XVI e XVII - Documentos, Lisbon / Macau: Centro Científico e Cultural de Macau, IP / Fundação Macau, 2012, vol. 2, p. 268.

20 See Giuseppe Sorge, Il 'Padroado' regio e la S. Congregazione 'de Propaganda Fide' nei secoli XIV-XVII, Bologna: Editrice Clueb, 1984; Giovanni Pizzorusso, Governare le missioni, conoscere il mondo nel XVII secolo. La Congregazione Pontificia de Propaganda Fide, Viterbo: Sette Città, 2014, pp. 111-114. 
Furthermore, the Crown made scarce use of the forum of the Inquisition in its allegations to the Holy See and its Congregations.

Conflicts between the missionaries of the Propaganda Fide and the Inquisition of Goa were not unheard of. As early as 1649, the governor of the bishopric of St. Thomas of Mylapore detained the French Capuchin Ephraim de Nevers, a missionary of the Propaganda Fide, and sent him to Goa to the Holy Office. ${ }^{21}$ Tried between January 1650 and November 1651, the Capuchin was condemned for propositions implying Calvinist affinities and for defending the priestly character of the English clerics and was finally compelled to hold a public abjuration on November $5,1651.22$

21 The events were described by François de la Boullaye-Le Gouz, Jean-Baptiste Tavernier and by Niccolò Manucci, especially the latter. Cf. François de la Boullaye-Le Gouz, Les voyages et observations dv sievr de la Bovllaye-Le-Govz gentil-homme angevin. Où sont décrites les religions, gouuernemens, \& situations des estats \& royaumes d'Italie, Grece, Natolie, Syrie, Perse, Palestine, Karamenie, Kaldée, Assyrie, grand Mogol, Bijapour, Indes Orientales des Portugais, Arabie, Egypte, Hollande, grande Bretagne, Irlande, Dannemark, Pologne, isles \& autres lieux d'Europe, Asie \& Affrique, ou il à seiourné, le tout enrichy de belles figures, Paris: Chez François Clusier, 1653, pp. 222-225; Jean Baptiste Tavernier, Les six voyages de Jean Baptiste Tavernier, Ecuyer Baron d'Aubonne, en Turquie, en Perse, et aux Indes : pendant l'espace de quarante ans .... Seconde partie, où il est parlé des Indes, et des Isles voisines, Paris: Chez Gervais Clusier et Claude Barbin, 1676, pp. 138-146 and Niccolò Manucci, Storia do Mogor. Or Mogul India 16531708, London: John Murray, 1907, vol. 3, pp. 428-480; J. A. Ismael Gracias, "Fr. Ephraim de Nevers e a Inquisição de Goa (1650-1651)": O Oriente Portuguêz, 810 (1911-1913); Glenn J. Ames, "The Perils of Spreading the True Faith in Asia. Fr. Ephraim de Nevers and the Goa Inquisition. 1650-1651": Proceedings of the Western Society for French History: Selected Papers of the Annual Meeting, 23 (1996), pp. 86-87.

22 Niccolò Manucci, who clearly had access to inquisitorial documentation, such as the accusatory libel and the abjuration of Friar Ephraim de Nevers, reports an accusation which coincides with the summary of the case sent to Lisbon by the inquisitors of Goa. In this document, it is possible to read that Nevers was convicted for "claiming and sustaining that the domine of the English was a good priest and had sacerdotal character and that the image of the Holy Trinity shouldn't be painted, nor should the cross be given latria worship, disapproving the use of images of figures in India, provoking scandal due do this [behavior]" (affirmar, e deffender que o domine dos Jnglezes era bom sacerdote, E tinha character sacerdotal, e que não se podia pintar a Jmagem da Santissima Trindade, nem se deuia adoração de latria a Crus não aprouar 0 uzo das Jmagens de uulto 
Glenn J. Ames, who examined the case from the point of view of religious competition in Asia between the clergy attached to the Portuguese Patronage and the Propaganda Fide, recognized in Nevers' prison an act of religious policy by an ecclesiastical authority (the governor of the bishopric) designed to halt the migration from Mylapore in favor of Madras and to ensure the destruction of the Capuchin mission. The Inquisition of Goa which, for Ames, "constituted perhaps the most effective and well-financed organization for setting the score with such competitors in the religious competition", therefore represented a resource aimed at blocking the greater dynamism of the Propaganda Fide missionaries. ${ }^{23}$

Although the case suggests that the Holy Office of Goa, as an ecclesiastical tribunal linked to the Crown of Portugal, supported the royal orders of hindering the missionaries of the Propaganda Fide and defended the Portuguese Patronage, an analysis of the broader chronology indicates that this interpretation cannot be linearly extrapolated for later situations of jurisdictional conflict.

Even if ongoing jurisdictional tensions marked the relationship between ecclesiastical agents of the Portuguese Crown and the apostolic vicars of the Propaganda Fide, the Portuguese priests and missionaries in the Estado da Índia did not always display signs of unease over the foundation of the new Congregation in 1622. On the contrary, the awareness of the limits of Portuguese power in Asia and the discomfort-if not resentment-regarding the protagonism of the Society of Jesus in this field motivated many secular and regular priests

nas partes da Jndia, dando com tudo isso escandalo). List of persons dispatched by the Goa Inquisition between 3 April 1650 and the auto-da-fé of 3 December 1651. Arquivo Nacional / Torre do Tombo [ANTT], Tribunal do Santo Ofício, Conselho Geral do Santo Ofício, maço 33, no. 1, fl. 23; Ames, “The Perils”, pp. 8688. For a discussion on the charges brought against Fr. Ephraim de Nevers see Paolo Aranha, "'Glocal' Conflicts. Missionary Controversies on the Coromandel Coast between the XVII and XVII Centuries": Michela Catto / Guido Mongini / Silvia Mostaccio (eds.), Evangelizzazione e globalizzazione. Le missioni gesuitiche nell'età moderna tra storia e storiografia, Città di Castello: Società Editrice Dante Alighieri, 2010, pp. 88-89.

23 Ames, "The Perils", pp. 84, 90 (quotation from page 84). 
to applaud the papal initiative. Some of them hoped for a renewal of the mission and a reduction of Jesuit influence. ${ }^{24}$

Likewise, the creation of the Propaganda Fide initiated regular communications between the Congregation and various ecclesiastical authorities of the Estado da Índia. The Holy Office did not remain on the sidelines of this epistolary exchange. In 1627, the Congregation had already corresponded with the inquisitor Francisco Borges de Sousa, asking him for information which ultimately failed to arrive because the letters were lost in a shipwreck. However, knowing how the Propaganda Fide sought out priests to whom it could entrust the Congregation's affairs in Asia, the inquisitor sent a detailed list of names to Rome. ${ }^{25}$ In another letter, sent two years later, Sousa stressed the need for the superiors of religious orders to send to Asia their best subjects to support the missions, another sign that imperial ecclesiastical agents did not see the creation of the Propaganda Fide in Goa as contradicting missionary enterprises under the auspices of the Padroado. ${ }^{26}$

The death of the inquisitor Francisco Borges de Sousa that same year did not prevent the Congregation from strengthening its ties with the tribunal. Among the most useful informers of the Propaganda Fide in Goa was Pedro Borges, who served as notary of the Holy Office since 1646. Author of "public reports sent to the Holy Congregation" and of a secret memorial given to the Pope, Borges would, however, become the object of the tribunal's attention. ${ }^{27}$ From various letters received in Lisbon, we infer that Borges left Goa without the authorization of the Inquisition or the General Council of the Holy Office, heading to Rome

24 See, for example, the letter of Fr. Miguel Rangel, OP, bishop of Cochin, to Philip IV, King of Spain, 1638. Archivio Storico de Propaganda Fide [ASPF], Scritture Originale Congregazioni Generali, vol. 109, fls. 118-118v, 126-126v.

25 Letter of Francisco Borges de Sousa, inquisitor of Goa, to the Congregation of Propaganda Fide, 13 October 1627, in Goa. ASPF, Scritture Originali riferite nelle Congregazioni Generali, vol. 98, f. 149.

26 Letter of Francisco Borges de Sousa, inquisitor of Goa, to the Congregation of Propaganda Fide, 22 February 1629, in Goa. ASPF, Scritture Originali riferite nelle Congregazioni Generali, vol. 98, fls. 141-141v. I would like to thank Kevin Soares for bringing this document to my attention.

27 Letter from Pietro Lippa, June 28, 1670. ASPF, Scritture Riferite nei Congressi, Indie Orientali e Cina, vol. 1B, f. 480. “[...] publiche relationi date alla Sac. Congregatione". 
by land, where he arrived in $1656 .{ }^{28}$ He must have returned to Asia in 1662 , as suggested by the express instructions from the General Council to the inquisitors at Goa to place Borges under arrest, whatever the cost. $^{29}$ He passed away shortly afterwards, for the General Council refers to his death in the letter of 1665 sent to the inquisitors, regretting that his "dishonors", "insubordination, and wrongdoings" were left without the desired punishment. ${ }^{30}$

The Congregation did not cooperate only with Pedro Borges. We know that the inquisitor himself, Paulo Castelino de Freitas, maintained regular correspondence with the Propaganda Fide, because he was the depositary of the estate of the deceased archbishop of Mira's effects, part of which belonged to the Congregation. ${ }^{31}$ In this epistolary exchange, of which we unfortunately do not know Freitas' answers, the secretary of the Propaganda Fide praised the inquisitor's "piety and zeal, with which he promotes the interests of the holy faith in those

${ }^{28}$ Letter from Francisco de Sousa Coutinho, Ambassador in Rome, to Afonso VI, King of Portugal, 12 March 1656, in: Jayme Constantino de Freitas Moniz, Corpo diplomatico portuguez contendo os actos e relações politicas e diplomaticas de Portugal com as diversas potencias do mundo desde o seculo XVI até os nossos dias, Lisbon: Typographia da Academia Real das Sciencias, 1907, vol. 13, p. 272; Letter from the General Council of the Holy Office to the Inquisitors of Goa, 27 March 1657, in Lisbon. ANTT, Tribunal do Santo Ofício, Conselho Geral do Santo Ofício, liv. 101, f. 161.

${ }^{29}$ Letter from the General Council of the Holy Office to the Inquisitors of Goa, 30 March 1662, in Lisbon. ANTT, Tribunal do Santo Ofício, Conselho Geral do Santo Ofício, liv. 101, f. 165v.

30 Letter from the General Council of the Holy Office to the Inquisitors of Goa, 10 April 1665, in Lisbon. ANTT, Tribunal do Santo Ofício, Conselho Geral do Santo Ofício, liv. 101, f. 173v. "desdouros", "desmandos, e desacertos".

31 Letters from the Secretary of Propaganda Fide to Fr. Giuseppe di Santa Maria and Paulo Castelino de Freitas, inquisitor of Goa, 1663. ASPF, Lettere e Decreti della Sacra Congregazione e Biglietti di Monsignor Segretario, vol. 45, fls. 64, 65, 68v, 69. Fr. Francesco Antonio di San Felice, OFMConv, was consecrated archbishop of Mira by Urban VIII and nominated apostolic administrator of Japan at the request of the Congregation of Propaganda Fide in 1637. However, he was prevented from journeying to the archipelago by the Portuguese authorities in Goa. See Lino M. Pedot, La S. C. de Propaganda Fide e le missioni del Giappone (1622-1838), Vicenza: Tipografia Pont. Vesc. S. Giuseppe, 1946, pp. 216-230. 
parts". 32 The Congregation had good reason to do so. As can be seen from the correspondence, Paulo Castelino de Freitas gave invaluable support to Fr. Giuseppe de Santa Maria, OCD, bishop of Hierapolis and apostolic vicar of Serra, actions that were much appreciated in Rome. ${ }^{33}$ At the same time, it is no less true that Paulo Castelino de Freitas was the one responsible for conducting the trial against Fr. Ephraim of Nevers, who, contrary to what Glenn J. Ames proposed, far from benefited from benign treatment by the tribunal. ${ }^{34}$ The prohibition on the celebration of the feast of Our Lady of Divine Providence of the Theatines by Freitas was also received in Rome with uneasiness, and the secretary wrote to the inquisitor requesting an explanation. 35

These examples show that the Inquisition was not a homogenous unit with an unambiguous position in jurisdictional disputes between the Crown of Portugal and the Propaganda Fide. Instead, the Holy Office required a detailed analysis of its members, especially its leading figures, to understand the role that the tribunal played in the controversies with the apostolic vicars in Southeast Asia. All the more so, after the beginning of the 1670 s, when the tribunal came to be subjected to jurisdictional restrictions by the Papacy.

32 Letter from the Secretary of Propaganda Fide to Paulo Castelino de Freitas, inquisitor of Goa, July 24, 1666. ASPF, Lettere e Decreti della Sacra Congregazione e Biglietti di Monsignor Segretario, vol. 52, f. 174v. “[...] della sua pietá, e del zelo, con che ella promoue gl'Jnteressi della santa fede in coteste parti".

33 Ibidem, f. 174v; Letter from the Secretary of Propaganda Fide to Paulo Castelino de Freitas, Inquisitor of Goa, January 1663. ASPF, Lettere e Decreti della Sacra Congregazione e Biglietti di Monsignor Segretario, vol. 45, f. 65.

34 Ames proposed this reading based on the sentence, which he considered light, and the change of prison from which Fr. Ephraim benefited. However, the Capuchin remained on trial for almost two years, contesting the prosecutor's accusation formalized in the libel and was confronted with the qualifications of his propositions. The actions of the inquisitors of Goa deserved, moreover, as Giuseppe Marcocci and José Pedro Paiva noted, a negative remark by the General Council for not having placed Fr. Ephraim in the custody of one of the Goa convents. Cf. Manucci, Storia do Mogor, pp. 439-461; Ames, “The Perils”, pp. 8788; Giuseppe Marcocci / José Pedro Paiva, História da Inquisição portuguesa. 1536-1821, Lisbon: A Esfera dos Livros, 2013, p. 232.

35 Letter from the Secretary of Propaganda Fide to Paulo Castelino de Freitas, Inquisitor of Goa, September 12, 1665. ASPF, Lettere e Decreti della Sacra Congregazione e Biglietti di Monsignor Segretario, vol. 52, f. 161. 


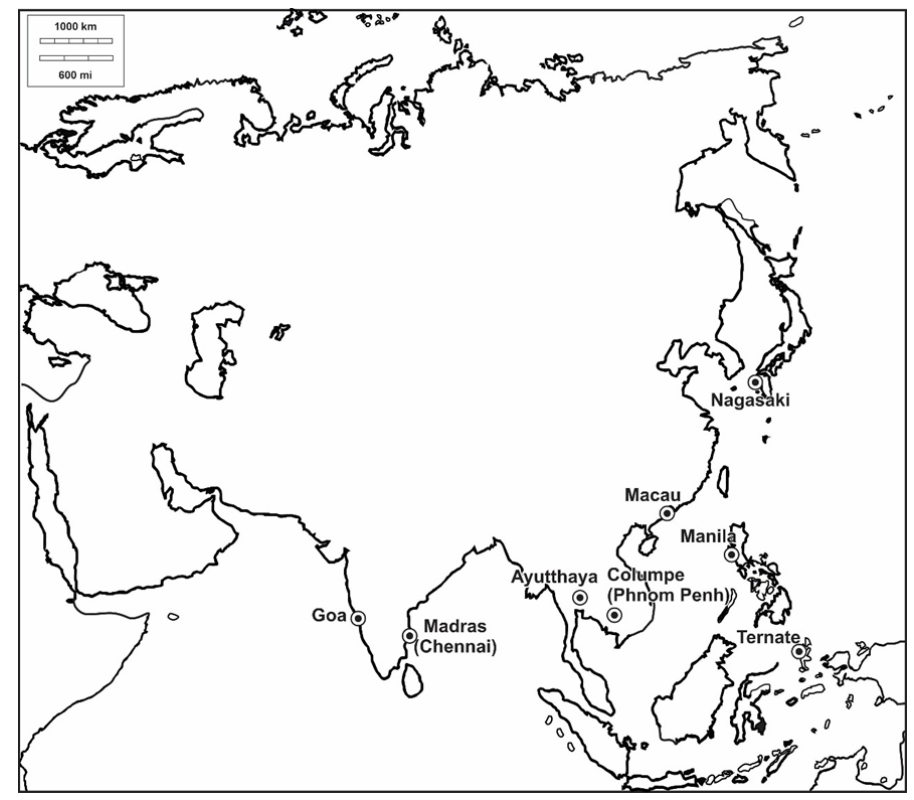

Locations of actual or intended projection of inquisitorial jurisdiction in Asia (17th century) (map by author).

\section{The Holy Office between the Portuguese Patronage and Propaganda Fide: Local Actions, Inquisitorial Decisions}

In Ayutthaya, the Portuguese settled in a 'campo' or 'bandel', forming a self-governing community that had grown according to the rhythms of the Portuguese diaspora in Southeast Asia, resulting from the exodus of fortresses or settlements taken by the Dutch such as Melaka or Makassar. From its original informality, the 'bandel' of Ayutthaya came to have a captain appointed by Goa and confirmed by the King of Siam. ${ }^{36}$

${ }^{36}$ Rita Bernardes de Carvalho, La présence portugaise à Ayutthaya (Siam) aux XVIe et XVIIe siècles, Paris: École Pratique des Hautes Études, 2006, pp. 91-103 (MA Thesis); Miguel Castelo Branco, “A época de ouro dos Protukét do Sião”: António Vasconcelos de Saldanha / Miguel Castelo Branco (eds.), Das partes do Sião. Exposição comemorativa do 500 aniversário das relações Luso-Tailandesas, Lisbon: Biblioteca Nacional de Portugal, Instituto do Oriente / ISCSP-UTL, 2011, p. 16; Stefan Halicowski Smith, Creolization and Diaspora in the Portuguese Indies. The Social World of Ayutthaya. 1640-1720, Leiden / Boston: Brill, 2011, 
The arrival of the apostolic vicars in Asia occurred in a most inconvenient time for the Portuguese Crown, still facing a war against the Habsburgs and a vacancy of virtually all its dioceses in Asia. The rank of bishops held by the apostolic vicars thus posed an aggravated difficulty for Portuguese authorities, especially in the face of the papacy's refusal to consecrate new prelates for Portuguese bishoprics after 1640 and the process of creation of the Société des Missions Étrangères de Paris between 1658 and $1663 .{ }^{37}$ Orders were sent to Goa with precise instructions for the arrest of Propaganda missionaries who reached Siam in 1662. However, the consented nature of the Portuguese presence in Ayutthaya prevented the implementation of such orders.

Indeed, after the arrival of Monseigneur Pierre Lambert de la Motte, titular bishop of Beirut and apostolic vicar of Cochinchina, in Ayutthaya in 1662 and in view of the obstacles that prevented his departure, the prelate had secured a stay permit from the King. The logistical difficulties in going to Cochinchina forced Lambert de la Motte to remain in Siam longer than intended, motivating during that period a rethinking of Ayutthaya's role in the strategy of establishing the apostolic vicariates in Southeast Asia and East Asia. ${ }^{38}$ However, at the same time, the forced and unexpected stay of the prelate in Ayutthaya

esp. Chapter 5: "O Campo Português. The Portuguese Quarter in Ayutthaya in the Wake of the Makassarese Diaspora".

37 As recently reminded by Tara Alberts, missionaries required the appropriate faculties to administer sacraments and license to operate in a given diocese. The appointment of figures that possessed full episcopal sacral authority introduced, as Alberts' apply put it, a "new layer of jurisdiction" in the Southeast Asian setting that conferred legitimacy to the activities of missionaries working beyond the auspices of the Portuguese Padroado. In France, the creation of a missionary institution comprised of secular priests between 1658 and 1663 facilitated the recruitment of missionaries to accompany the apostolic vicars. Tara Alberts, Conflict and Conversion. Catholicism in Southeast Asia. 1500-1700, Oxford: Oxford University Press, 2018, pp. 18, 34-46; Françoise Fauconnet-Buzelin, "Réforme romaine et esprit français. La Société des Missions Étrangères de Paris": Revue des sciences religieuses, 80: 2 (2006), pp. 167-178, online: https://doi.org/10.4000/rsr.1872 [12-10-2020].

38 See, in extensu, Henri Chappoulie, Aux origines d'une Église. Rome et les missions d'Indochine au XVIIe siècle, Paris: Bloud et Gay, 1943, vol. 1, and Alain Forest, Les missionnaires français au Tonkin et au Siam. XVIIe-XVIIIe siècles. Analyse comparée d'un relatif succès et d'un total échec, Paris / Montreal: L'Harmattan, 1998, vol. 1. 
contributed to the growing discomfort between the French missionaries and the small nucleus of Padroado missionaries installed in the 'bandel': four Jesuits from the province of Japan and two Dominican friars, one of whom was Luís Fragoso, commissary of the Holy Office.

In Ayutthaya, the continued presence of Pierre Lambert de la Motte generated tensions. It prolonged the challenge of the newcomers to the rights of the Patronage invoked by the Portuguese missionaries, but from a delicate position. In fact, as apostolic vicar of Cochinchina, Lambert de la Motte had no jurisdiction over Siam, something of which the prelate was aware and that he tried to manage as long as he could, taking his time to reveal his pontifical patents to the Portuguese missionaries. ${ }^{39}$ Furthermore, the prelate's stay contributed to the deterioration of the relationship between the two groups of missionaries. His criticism of the quality of the conversions by the Patronage's priests was, above all, directed at the Society of Jesus, for which he nourished an undisguised disdain. ${ }^{40}$ Moreover, Pierre Lambert de la Motte's reproach towards the missionaries of the Patronage for their intransigence in denying recognition of his jurisdiction was inseparable from a strongly anti-Jesuitical discourse. ${ }^{41}$

The evolution of the conflict between the missionaries of the Patronage and of Propaganda is mostly known due to the studies of Henri Chappoulie and Alain Forest, so it is not necessary to revise them in detail at this point. I wish to emphasize the way in which the Holy Office participated in this dispute. ${ }^{42}$ The events in question took place

${ }^{39}$ He did so only in 1670. Chappoulie, Aux origines d'une Église, pp. 138, 160.

40 Chappoulie, Aux origines d'une Église, pp. 153-159.

${ }^{41}$ António Vasconcelos de Saldanha rightly pointed out that the defence of the rights of the Portuguese Crown implied, to a large extent, a convergence with the Society of Jesus, which, on the field, played a fundamental role in opposing the entrenchment of the missions of Propaganda Fide. António Vasconcelos de Saldanha, De Kangxi para o papa, pela via de Portugal. Memória e documentos relativos à intervenção de Portugal e da Companhia de Jesus na questão dos ritos chineses e nas relações entre o imperador Kangxi e a Santa Sé, Macau: Instituto Português do Oriente, 2002, vol. 1, pp. 20-24.

42 Chappoulie, Aux origines d'une Église, pp. 151-153; Forest, Les missionnaires français, pp. 183-184; Dirk Van der Cruysse, Siam and the West. 1500-1700, Chiang Mai: Silkworm Books, 2002, p. 161; Halicowski Smith, Creolization and Diaspora, pp. 289-291 and appendixes 9-10. 
between May and December 1666 in Ayutthaya. According to the preserved accounts - sent to the Congregation of Propaganda Fide and later to that of the Holy Office-Pierre Lambert de la Motte challenged a proposition presented by Luís Fragoso on the validity of being able to sponsor a confirmand in the sacrament of Confirmation. ${ }^{43}$ The prelate issued a public edict ordering that in the territories under his jurisdiction none of the regular clergy be admitted as sponsors. ${ }^{44}$ Fragoso invoked his own capacity as a commissary of the Holy Office, and declared that in trying to qualify propositions that had been validated by the Supreme Inquisition of Spain, Lambert de la Motte

"took upon himself the jurisdiction of the inquisitors, who were the only censors of the faith in the Eastern provinces, because to them, and not to others, belonged, to examine, and to censor opinions, which are against the faith and good customs". 45

He questioned Lambert de la Motte's authority to meddle with the inquisitors' jurisdiction. Fragoso also stated that all acts in this field were to be considered null until the Holy Office of Goa took a decision on them. ${ }^{46}$ The commissary and the apostolic vicar maintained a bitter exchange of allegations until November 30. On that day Fr. Luís Fragoso declared Lambert de la Motte a rebel, "for denying the jurisdiction [...] of the ministers of that holy tribunal," and excommunicated him. ${ }^{47}$ Then Lambert de la Motte revealed the trump card that, in Forest's opinion,

${ }^{43}$ He based himself on the work Singularia theologiæ moralia ad septem ecclesiæ sacramenta by the Jesuit Antonio Quintanadueñas, printed in Seville in 1645. Congregation of August 4, 1670. ASPF, Scritture Riferite nei Congressi, Indie Orientali e Cina, vol. 1B, f. 656; Congregation of September 3, 1671. ACDF, 0 1-n, no. 6, f. 603.

44 The edict, dated 31 May 1666, was notified to Friar Luís Fragoso two days later. Ibidem, f. 603v.

45 Ibidem, f. 604v: “[...] si arrogasse la giurisdittione de'gl'Jnquisitori, ch'erano soli Censori della fede nelle Prouincie Orientali, perche a'loro apparteneua, e non ad altri, essaminare, e censurare le opinioni, che sono contra la fede; e buoni costumi"; see also the Congregation of August 4, 1670. ASPF, Scritture Riferite nei Congressi, Indie Orientali e Cina, vol. 1B, fls. 656v.

${ }^{46}$ Congregation of September 3, 1671. ACDF, 0 1-n, no. 6, f. 604v.

47 Congregation of August 4, 1670. ASPF, Scritture Riferite nei Congressi, Indie Orientali e Cina, vol. 1B, fls. 657; quotation from the Congregation of September 3, 1671. ACDF, 0 1-n, no. 6, f. 606v: “[...] per hauer denegata la giurisdittione [...] a'i ministri di quel santo tribunale". 
motivated him to confront the Jesuits and Dominicans of Ayutthaya so directly. The prelate claimed that French missionary Louis Chevreuil had obtained in December 1665 a commission from Fr. Paulo da Costa, governor of the bishopric of Melaka, for the apostolic vicar to administer sacraments in his area of jurisdiction, an act that was understood as a transfer of powers. ${ }^{48}$ On December 2, 1666, Luís Fragoso posted an excommunication sentence against Lambert de la Motte in the church of the Rosary and in that of the Jesuits, even placing under arrest a man who later visited the prelate. ${ }^{49}$ Fragoso admonished Lambert de la Motte for usurping of the Inquisition's exclusive jurisdiction. In the monitory of December 2, he also alluded to the intrusion of the apostolic vicar into the jurisdiction of the bishops of Melaka and Macau without proper authority. In his words, the prelate "was once again usurping the jurisdiction that did not belong to him, but rather [belonged] to the Holy Office and to the Bishops".50

In the immediate aftermath, the outcome of this controversy resembled earlier episodes in Southeast Asia and East Asia where inquisitorial jurisdiction had been invoked to settle jurisdictional disputes, and a stalemate ensued. ${ }^{51}$ Luís Fragoso could not enforce the censures that he issued against the prelate to put an end to the conflict. At the same time, the protection afforded by the King of Siam made it impossible to apply the orders of the Viceroy, who ordered the subjects of the Crown of Portugal to prevent the access of the vicars to their missions. ${ }^{52}$ In 1677, the regent Peter, future Peter II (regent 1667-1683; King 1683-1706) was confronted with a letter from the viceroy Luís de Mendonça Furtado, who declared that it was impossible to enforce the

\footnotetext{
48 Forest, Les missionnaires français, pp. 182-183.

49 Unfortunately, we don't know his identity. Congregation of August 4, 1670. ASPF, Scritture Riferite nei Congressi, Indie Orientali e Cina, vol. 1B, f. 657; Congregation of September 3, 1671. ACDF, 0 1-n, no. 6, f. 606v; Copy of the monitory of Friar Luís Fragoso, commissary of the Holy Office in Siam, December 2, 1666. ARSI, Jap.Sin. 76, fls. 70-70v.

50 Ibidem, f. 70: "[...] de nouo hia uzurpando a jurdição que lhe não competia assi pertençente ao Sancto offiçio, como aos ordinarios".

51 Miguel Rodrigues Lourenço, A articulação da periferia. Macau e a inquisição de Goa (c. 1582-c. 1650), Lisbon / Macau: Centro Científico e Cultural de Macau, IP / Fundação Macau, 2016, pp. 266-285.

52 Chappoulie, Aux origines d'une Église, p. 138.
} 
regulations to send foreign bishops back to the kingdom because they did not enter the domains of the Crown. ${ }^{53}$

\section{Inquisition and Defense of the Patronage}

The confrontation between Fr. Luís Fragoso and Pierre Lambert de la Motte was not an especially valued episode in the dispute between the Crown of Portugal and the Holy See about the former's rights as Patron. In fact, the defense of these rights was predominantly based on the diocesan geography and its respective territorial jurisdiction. ${ }^{54}$ The work of D. Luís de Sousa, archbishop of Braga and Portuguese ambassador to Rome (1675-1682), which systematized the Crown's claims about its Patronage during this period, is a clear example of this. On only one occasion of his Demonstratio Juris does it refer to the existence of a commissary of the Holy Office in Siam:

"On the contrary, near the palace of Siam there is a copious and large crowd of Portuguese, divided into numerous families, with their own republic governed separately by a Portuguese minister appointed by our Viceroy and with a church, with clergy, with a Vicar, or Governor of the Bishopric, with a Commissary of the Holy Office elected by the Inquisition of Goa, and with a college of the Society of Jesus." 55

However, this reference to a commissary is part of a general description of the Ayutthaya 'bandel' and was not emphasized nor exploited as a

53 Letter of Luís de Mendonça Furtado e Albuquerque, viceroy of India, to D. Pedro, regent of Portugal, 13 January 1677. Arquivo Histórico Ultramarino [AHU], Conselho Ultramarino, Índia, cx. 54, doc. 117.

54 Chappoulie, Aux origines d'une Église, Paris: Bloud et Gay, 1948, vol. 2, pp. 1-25; Ângela Barreto Xavier / Fernanda Olival, "O padroado da coroa de Portugal. Fundamentos e práticas”: Ângela Barreto Xavier / Federico Palomo / Roberta Stumpf (eds.), Monarquias ibéricas em perspectiva comparada (sécs. XVI-XVIII). Dinâmicas imperiais e circulação de modelos administrativos, Lisbon: Instituto de Ciências Sociais, 2018, pp. 142-144.

55 D. Luís de Sousa, Demonstratio juris patronatus portugaliæ regum. Curante J. H. da Cunha Rivara, Panaji: Imprensa Nacional, 1860, p. 132: "[...] Immo prope Regiam Siamensem copiosa, lataque Lusitanorum multitudo, numerosis divisa familiis, cum propria separatim Republica gubernata a Lusitano ministro ad Pro Regis nostri nominationem deputato, nec non cum Ecclesia, cum Clero, cum Vicario, seu Gubernatore Episcopatus, cum Commissario S. Officii a Goensi Inquisitione electo, et cum Collegio Societatis Jesu". 
criterion for jurisdiction, but rather as an element that attested to the presence of Portuguese institutions and forms of government in the settlement. Nevertheless, the office of commissary was not mentioned in a witness statement drawn up at the request of the regent Peter by Francisco Barreto de Pina in 1681. Pina's intentional designation as "Captain-Major of the Catholic colony that the Portuguese have in this Kingdom of Siam, and of those who trade in it" manifests a range of criteria that find a parallelism in the work of D. Luís de Sousa: the presence of royal justice; vassals who constituted a colony; the Catholic nature of the colony. Required to inform the regent about the Catholic communities of those territories, the Captain-Major questioned several witnesses on the matter, which produced a testimony akin to the statement in the Demonstratio Juris. Invited to provide a characterization about the 'bandel' of Siam, the witnesses pointed out that it was a village formed by the Portuguese diaspora of Macau, Makassar and Cambodia; composed of Portuguese, "their children, and grandchildren, and more people of their families" and not of catechumens or local neophytes; with the presence of priests and vicars (vigários da vara) "of the jurisdiction of Goa" and members of the religious orders who administered the sacraments in a church; with both "captain and judge" provided by the viceroys of Goa with jurisdiction over the residents and those who came about to trade there. ${ }^{56}$ The Holy Office is notoriously absent from this list of ties to the Crown of Portugal, perhaps because all of these elements authorized the jurisdiction of the tribunal-and not the other way around-or because, as we will see, there was no commissary in the 'bandel' at the time.

Meanwhile, the Society of Jesus emphasized that the Holy Office's jurisdiction was precisely one of the ways in which the presence and behavior of the vicars of the Propaganda Fide (especially Pierre Lambert de la Motte) challenged the Crown's rights of Patronage. In his 1682 Apologia, the French Jesuit Joseph Tissanier criticized a report sent by the apostolic vicars to the Pope for concealing that the Portuguese living in the Kingdom of Siam "have a city, or colony, in

56 Witness statement drawn up by the ecclesiastical judgeship of the Portuguese settlement of Ayutthaya, April 18-June 16, 1681. ARSI, Jap.-Sin 76, fls. 238-242v: "[...] seus filhos, e nettos, e mais Gente de sua famillia"; "da jurisdição de Goa"; "capitão e justiça". 
which a Governor, a Judge, and a commissary of the Holy Inquisition, all Portuguese, are present and exercise their offices". 57

In the year of the controversy between Luís Fragoso and Pierre Lambert de la Motte, the Jesuits of the Province of Japan requested the diocesan court of Macau to draw up a witness statement of the events in Siam. In this report, the provincial Manuel Rodrigues stated that the apostolic vicar had requested the submission of the Jesuits present in the kingdoms and provinces that he claimed were under his jurisdiction, despite the fact that

"in many of them [the aforementioned places] the prelates of Melaka and China [were] in possession [i.e. in office] as belonging to the Royal Patronage of the Kings of Portugal".58

He added, furthermore, that Pierre Lambert de la Motte censored "propositions of a Catholic and religious author [i.e. Antonio Quintanadueñas], which in the domains of Portugal is a prerogative of the tribunal of the Holy Office", thus insinuating a challenge to one of the jurisdictional spheres of the Crown. ${ }^{59}$

Nonetheless, the Holy Office's jurisdiction did not play a significant role for the Society of Jesus during its quarrel with the apostolic vicars. In these years, the Jesuits understood that the Holy Office would not be of much value in their dispute with the apostolic vicar of Cochinchina. Indeed, the correspondence sent by the General Council of the Holy Office to the Inquisition of Goa, following the clash between Fragoso and

\footnotetext{
57 Summary of reasons given by Father José Tissanier, SJ, on 30th December 1682, in Macau, proving that the Jesuits were not disobedient to the Apostolic See, s/d (post. 1684). ARSI, Jap.-Sin. 163, fl. 213v: “[...] hanno una Città, ò Colonia, assai riguardeuole, nella quale si trouano et esercitano i loro officij un Gouernatore, un Giudice, et un Commissario della Santa Jnquisitione tutti Portoghesi".

58 Petition of Fr. Manuel Rodrigues, SJ, Visitor of the Province of Japan, to Fr. Miguel dos Anjos, Governor of the bishopric of China, 22 October 1666, in Macau. ARSI, Jap.-Sin. 76, fls. 51v-52: “[...] em muitos delles de posse como pertencentes ao Real Padroado dos senhores Reis de Portugal os Perlados ordinarios de Malaca, e da china".

59 Ibidem, fls. 52-52v: "[...] proposicões de Autor Catholico e Religioso, o que nos senhorios de Portugal he proprio do Tribunal do santo officio".
} 
Lambert de la Motte, shows that the inquisitors had withdrawn their commissary and his commission. 60

The decision may come as a surprise. There were, of course, solid reasons for implementing the measure. In the Estado da Índia, the institutionalization of the figure of the commissary of the Holy Office had not been done without strong discomfort for the tribunal. Due to the slow definition of the commissary's functions and powers within the Portuguese inquisitorial system itself, the commissaries, especially those from the most remote parts, were often involved in conflicts of a jurisdictional nature. ${ }^{61}$ The tribunal was thus frequently confronted with successive complaints against the abuse of competences of its commissaries. It is therefore understandable that, faced with a new potentially compromising situation, the tribunal decided to withdraw the commission of Fr. Luís Fragoso, a decision that it would later go back on. Indeed, in a letter sent to the inquisitors of Goa in 1672, Pierre Lambert de la Motte was astonished "that after being removed from the post of commissary of the Holy Office, Fr. Luís Fragoso was reinstated a second time". 62

However, the tribunal also withdrew the commission from Fr. Luís Fragoso, because the controversy had not gone unnoticed in Rome. Lambert de la Motte had lodged a complaint with the Congregation of Propaganda Fide, which in 1670 examined the case and sent it later to the Congregation of the Holy Office (1671). Neither did Lisbon ignore the case. The inquisitors had already informed the General Council on the matter before 1670, since in that year the board showed satisfaction that "the differences in Siam between the French Bishop and the

60 It is not clear if he was immediately replaced. The soonest we find another mention to a commissary in Ayutthaya is in 1685. See the Summary of witnesses drawn by Fr. Domingos de Santa Ana, commissary of the Holy Office in Siam, 17 26 September, 1685. AGN, Inquisición, vol. 675, exp. 3, f. 367-373.

61 Lourenço, A articulação da periferia, pp. 53-68.

62 Letter of Pierre Lambert de la Motte, bishop of Beirut and Apostolic Vicar of Cochinchina, to the Inquisitors of Goa, November 23, 1672, from Siam: "[...] quod Pater Ludouicus fragoso qui prius e gradu comissarii sanctæ inquisitionis fuerat eiectus iterum restitutus fuerit". ASPF, SC Indie Orientali, Cina, vol. 1, f. 605v. Copy at the Biblioteca da Ajuda de Lisboa [BAL], Cód. 46-XI-1, f. 175. I would like to thank Prof. António Andrade for his assistance in the analysis of this document and Prof. António Guimarães for providing a complete translation. 
commissary of the Holy Office are already settled".63 Clearly, the Portuguese Inquisition thought the matter was well in hand when, in 1671, it was surprised by a letter from the papal nuncio Francesco Ravizza in which he reported that he had been commissioned to communicate a decree from the Congregation of the Holy Office concerning the commissary Luís Fragoso.64 The decree, dated September 3, 1671, established that the sentence declared by the Dominican was null and void and that the Inquisition of Goa should no longer resort to his services. On the contrary, he should be expelled from Siam. 65

The new Inquisitor General, D. Pedro de Lencastre, obeyed the decision, commissioning the Goa Inquisition to execute the decree.66 The order must have taken a long time to be executed in its fullness, since the matter was still addressed in the correspondence of 1674 and 1676. ${ }^{67}$ However, a consultation of the Conselho Ultramarino (Overseas Council) in 1677 already stated that "he had the commission revoked, and [was] later totally deprived [of it], and ordered to leave Siam by virtue of a decree of the Sacred Congregation of the Holy Office". ${ }^{68}$ The dismissal of Fr. Luís Fragoso must have taken place only in 1675. A

${ }^{63}$ Letter of the General Council of the Holy Office to the Inquisitors of Goa, 26 March 1670. ANTT, Tribunal do Santo Ofício, Conselho Geral do Santo Ofício, liv. 101, fl. 181v: "[...] ja compostas as differenças do sião entre o Bispo Francez e o Commissario do santo officio".

64 Letter of Francesco Ravizza, papal nuncio in Portugal, to the General Council of the Holy Office, 22 October 1671. ANTT, Tribunal do Santo Ofício, Conselho Geral do Santo Ofício, liv. 102, f. 2v.

65 Decree of the Congregation of the Holy Office of 3 September 1671. ACDF, 0 1-n, no. 6, f. 609. Copy at ANTT, Tribunal do Santo Ofício, Conselho Geral do Santo Ofício, liv. 102, fls. $2 \mathrm{v}-3$.

66 Letter of D. Pedro de Lencastre, Inquisitor General of Portugal, to the Inquisitors of Goa, 27 February 1672. ANTT, Tribunal do Santo Ofício, Conselho Geral do Santo Ofício, liv. 102, f. 2 v.

${ }^{67}$ Letters of the General Council of the Holy Office to the Inquisitors of Goa, 16 March 1674 and 17 March 1676, Lisbon. ANTT, Tribunal do Santo Ofício, Conselho Geral do Santo Ofício, liv. 102, fls. 7, 12.

68 Consultation of the Conselho Ultramarino with the King of Portugal and his Reply, on 18 and 20 March 1677, Lisbon. ANTT, Tribunal do Santo Ofício, Conselho Geral do Santo Ofício, liv. 102, f. 17: "[...] lhe foi remouida a Commissão, e despois priuado de todo, e mandado sair de Sião, em virtude de hum Decreto da Sagrada Congregação do Santo Officio". 
letter from the Dominican to the Conselho Ultramarino, dated January 1674, stated that the French bishops had succeeded in exerting pressure to have the commission of the Holy Office revoked, despite his 31 years of office. ${ }^{69}$ In 1675, the decision was definitively executed, since Fr. Manuel Soares, SJ, wrote on November 22 that in Ayutthaya arrived

"two or three months ago, a Pope's bull or a brief against a Dominican friar that was accepted, as these French Bishops say, by the Inquisition of Portugal and Goa [...] without listening to the said friar, condemned to no longer be a Commissary nor to have any office in the Inquisition, and to be banished from this Kingdom of Siam".70

As we have said, the missionary project of the Propaganda Fide was not viewed by all Portuguese sectors in the same way. As evidenced by the cases of Paulo Castelino de Freitas and Pedro Borges, the Holy Office cannot be analyzed as a purely institutional actor in view of the challenges posed to the royal patronage. In fact, everything indicates that the favorable disposition shown by Castelino de Freitas towards the Propaganda Fide was maintained by his successor, Francisco Delgado e Matos. This inquisitor, appointed in 1666, expressed in 1675 the desire to obtain "the privileges of apostolic missionary", given the many services which the tribunal of the Holy Office did in East India for the propagation of the faith. In the letter, he even recommended the convenience of having a nuncio or at least an apostolic judge with the faculty of collector in those parts, offering himself to assume this task. ${ }^{71}$ Moreover, if one were to believe the correspondence sent from Asia to

69 Letter from Fr. Luís Fragoso, OP, Commissary of the Holy Office in Siam, to D. Pedro, Regent of Portugal, 19 January 1674, in Siam. AHU, Conselho Ultramarino, Índia, cx. 52, doc. 151. Publ. in Smith, Creolization and Diaspora in the Portuguese Indies, pp. 334-337.

70 Letter from Fr. Manuel Soares, SJ, to the Assistant Priest of Portugal in Rome, 22 November 1675, from Siam. ARSI, Jap.-Sin. 76, f. 166: “[...] hauerà dous ou 3 meses hũa bulla ou hum breue do papa passado como disem estes Bispos Franceses pella ynquisição de portugal e de goa contra hum frade Dominico [...] sem ser ouuido o dito frade condenado a que não fosse mais comissario nem tiuesse mais cargo algum na ynquisição, e que fosse desterrado deste Reino de Sião".

${ }^{71}$ Letter from Francisco Delgado e Matos, Inquisitor of Goa, 1675. ASPF, Scritture Riferite nei Congressi, Indie Orientali e Cina, vol. 2, fl. 32: “[...] i Priuilegij di Missionario Apostolico". 
Rome during the first half of the 1670s, Francisco Delgado e Matos served as a deterrent to those who sought to hinder the missionaries of Propaganda. In 1675, Charles Sevin wrote to the mission procurators in Paris that

"the Inquisitor of Goa denied a patent as a Commissary of the Holy Office for Macau to a Portuguese priest who removed Mr. Chevreiul from Cambodia, on the grounds that he had been reported to Rome, and that consequently he was unworthy of such an office, having also badly administered it; and this Inquisitor declared himself protector for the execution of the bulls of the Holy See".72

This "Portuguese priest" was António de Morais Sarmento, appointed that same year as governor of the bishopric of China by the chapter of the archbishopric of Goa during the vacancy of the See. ${ }^{73}$ In accordance with a royal charter of 1650 , the offices of governor of the bishopric of China and commissary of the Holy Office in Macau were to be entrusted to the same person, which would oblige the tribunal to send Morais Sarmento a commission which constituted him as its authorized representative. ${ }^{74}$ However, on the same day that the chapter communicated its choice to the Holy Office, the inquisitor disputed the election, stating that Fr. António de Morais Sarmento "cannot be commissary of the Holy Office". ${ }^{75}$ The letter is silent as to the reasons

72 Letter of Charles Sevin to the Procurators of the Mission in Paris, 26 December 1676, from Siam. ASPF, Scritture Riferite nei Congressi, Indie Orientali e Cina, Miscellanea 17, s/f (letter Q): “[...] l’Jnquisitore di Goa há negato patenti di Commissario del s. Offitio per macao ad un sacerdote Portughese il quale haueua leuato da Camboia il signor Cheureiul, dicendo, che egli era informato á Roma, e che consequentemente era indegno di tal Offizio hauendolo anche malamente amministrato; e questo Jnquisitore si é dichiarato Protettore per l'executione delle Bolle della S. Sede".

73 Copy of a ruling by the Ecclesiastical Chapter of Goa, 22 April 1675, in Goa. Seminário de S. José de Faro, Notícias para a História Eclesiástica da Igreja Primacial de Goa, fl. 180v. I would like to thank Fr. José Pedro Martins, dean of the diocese of Algarve, for bringing this volume to my attention.

74 Copy of a letter from King John IV of Portugal to the Holy Office of the Inquisition of Goa, on 26 March 1650, in Lisbon, copied by the Inquisition of Goa on 16 February 1671, in Goa. Rodrigues Lourenço, Macau e a Inquisição, vol. 2, p. 310.

75 Copy of a letter from Francisco Delgado e Matos, Inquisitor of Goa, to the Ecclesiastical Chapter of Goa, 27 April 1675, in Goa. Seminário de S. José de Faro, Notícias para a História Eclesiástica da Igreja Primacial de Goa, f. 181v: “[...] não pode ser Commissario do Santo Officio". 
considered in the Inquisition, which led the chapter to disregard the objections of the tribunal. ${ }^{76}$ The inquisitors then wrote to the Inquisitor General, reporting Morais Sarmento's lack of qualities for the position, but justifying them apparently by the fact that he had been expelled from the Society of Jesus. ${ }^{77}$ The opposition had no effect, since the inquisitor general determined that such motives were not sufficient, and that "should the elected have no impediment, the commissariat of the Holy Office should not be separated from the government [of the bishopric]".78

It was not the first time that António de Morais Sarmento found himself involved in controversies with the French missionaries. In fact, Morais Sarmento was in the 'bandel' of the Portuguese in Ayutthaya in 1666, at the time of the dispute between Fr. Luís Fragoso and Pierre Lambert de la Motte. It was precisely to him that the Dominican instructed the apostolic vicar to show his apostolic patents. Morais Sarmento was also present to the following due diligences until Fragoso's declaration of excommunication of 2 December 1666.79

The letter from Sevin leaves no room for doubt that Delgado e Matos refused to grant the commission to the "Portuguese priest" because he had forcibly removed the missionary Louis Chevreuil from Cambodia. As a matter of fact, António de Morais Sarmento met Louis Chevreuil during his stay in Cambodia in 1670, acting at the time as visitor of the bishopric of Melaka appointed by the chapter of the archbishopric of Goa. Chevreuil, of whom the same Morais Sarmento would later describe as "volatile in his discourse and reckless" 80 was the priest who

76 Copy of a letter from the Ecclesiastical Chapter of Goa to the tribunal of the Holy Office of Goa, 27 April 1675 in Goa. Seminário de S. José de Faro, Notícias para a História Eclesiástica da Igreja Primacial de Goa, f. 181.

77 The same information is mentioned by Louis Chevreuil. Letter from Louis Chevreuil, August 6, 1674. ARSI, Jap.-Sin. 162, fl. 380.

${ }^{78}$ Letter from the General Council of the Holy Office to the table of the Inquisition of Goa, of 2 April 1677, Lisbon. ANTT, Tribunal do Santo Ofício, Conselho Geral do Santo Ofício, liv. 102, f. 15: "[...] não tendo o Eleito impedimento, não se separe a Commissaria do Santo Officio do gouerno".

${ }^{79}$ Copy of the monitory of Fr. Luís Fragoso, Commissary of the Holy Office in Siam, December 2, 1666, in Siam. ARSI, Jap.-Sin. 76, fls. 70-70v.

80 Certificate of António de Morais Sarmento, Governor of the bishopric of China, 28 November 1682, in Macau. BAL, Cód. 49-V-19, f. 175: “[...] vario no seu discurço e temerario". 
had obtained from Paulo da Costa the delegation of powers exhibited by Pierre Lambert de la Motte to Fr. Luís Fragoso.

The more recent interactions of Chevreuil with another figure of ordinary ecclesiastical authority would have, this time, a completely different outcome. The accounts of what happened between António de Morais Sarmento and Louis Chevreuil in Cambodia have different nuances depending on whether the documentation was written by the Portuguese or the French side. Morais Sarmento, in statements he produced at the request of Fr. Francesco Saverio Filippucci, SJ, provincial of Japan, several years after the facts, would say that during his stay he received from Chevreuil several complaints against the residents and priests of the 'bandel' of Columpe (Phnom Penh), without him being able or willing to prove them. Therefore, "we determined, and asked that he went to Macau to report the news of the things he had proposed to the proper authority", that is, to Fr. Miguel dos Anjos, then governor of the bishopric of China. ${ }^{81}$ It was the latter who ultimately suspended his holy orders and sent him to Goa, without António de Morais Sarmento implying any other institutional framework at play than that of the ordinary jurisdiction. In this matter, he strayed from the terms of the petition of Filippuci. The provincial expressly alluded to the office of commissary of the Holy Office that Fr. Miguel dos Anjos also held, stating that he had sent Chevreuil "to Goa, to the Inquisition of that State [i.e. the Estado da Índia]".82

This account could not be more diverse from the ones by the missionaries of the Missions Etrangères. In these texts, the gentleness and cordiality suggested by António de Morais Sarmento in his treatment of Chevreuil is contrasted by reports that he was "seized on a boat that carried him to Macau on the fourth of August in 1670", and that he was imprisoned for five months before being remitted to Goa. ${ }^{83}$

81 Ibidem, f. 175: “[...] mandamos, e pedimos fosse a Macao a dar parte a quem tocaua o ter noticia das couzas que tinha proposto".

82 Petition by Fr. Francesco Saverio Filippucci, SJ, Provincial of the Japan Province of the Society of Jesus, before Fr. António de Morais Sarmento, Governor of the bishopric of China, s/d (c. 28 November 1682, Macau). BAL, Cód. 49-V-19, f. 174: "[...] a Goa, a Jnquizição daquelle estado".

83 Relation des missions et des voyages des evesques vicaires apostoliques, et de leurs ecclesiastiques. És années 1672, 1673, 1674, \& 1675, Paris: Chez Denys 
It would not be the only mention of the violence exercised on Louis Chevreuil in the printed letters of the French missionaries, of which one was even reported in the first person:

"[António de Morais Sarmento] had a famous libel published against me, no doubt at the request of the Jesuits, who were in this Kingdom [Cambodia] and who were said to be of the same sect, and a Jesuit himself made this publication in which he declared me a suspect in the faith and after having been cited by the Inquisition, they sent me on one of their ships to Macau where I was kept for five months [.... I was finally sent to Goa for the Holy Office where I arrived after four months of a very difficult journey where I had the misfortune of being incarcerated once again". 84

The same letter from Chevreuil alludes to the fact that, once in Goa, he was released after only two sessions with the inquisitors, thus emphasizing the patent injustice he had suffered, for which Morais Sarmento and the Jesuits shared responsibility. 85 The Inquisition of Goa was once again placed on the path of the vicars of the Propaganda Fide, all the more so since the arrest of Louis Chevreuil was the second to occur to a French missionary under the tutelage of the apostolic vicar of Cochinchina in just half a decade. In December 1667, Pierre Brindeau, who had been sent by Lambert de la Motte to Macau on June 231665 to prepare his entry into China, was arrested by Fr. Miguel dos Anjos and

Bechet, 1680, p. 85: “[...] enlevé sur une barque que le porta à Macao le quatreéme du mois d'Aoust en 1670".

84 Copy of a letter by Louis Chevreuil, August 6, 1674. ARSI, Jap--Sin. 162, fl. 380: "[António de Morais Sarmento] hizo publicar un libelo famoso contra mi, sin duda por solicitacion de los Jesuitas, que estauan en este Reyno y los quales se me ha dicho ser de la misma secta, Y un Jesuita mismo hizo esta publicasion en la qual me declaraua por sospechoso en la fe y despues de auerme intimado los ordenes por la jnquisicion me embarcaron [en] Vno de sus baxeles para Macan en donde me han tenido el tiempo de cinco meses [...] en fin me embiaron preso por el sancto oficio a Goa en donde llegue despues de quatro meses de una nauegacion bien deficultosa en donde tube dicha de ser otra uez encarcelado".

${ }^{85}$ Another source mentions three sessions: "[...] ayant comparu trois fois devant ses Juges, ils furent si convaincus de la pureté de ces sentiments, \& si édifiez de son humilité, \& de sa patience, qu'ils le mirent en pleine liberté, \& resolurent de le renvoyer avec honneur, sans neanmoins luy vouloir donner acte écrit qui servit de justification à sa conduite". Relation des missions et des voyages, p. 86. 
sent to Goa, where he was handed over to the Holy Office ${ }^{86}$. Again, the reports differ. In the French sources, Brindeau was initially well received in Macau, either by the Captain General or by the governor of the bishopric. The latter reportedly even occupied him in confessing and preaching, and Brindeau still had time to study the Chinese language. ${ }^{87}$ For its part, the Society of Jesus tried to shake off the accusations of interference in the sending of Brindeau-especially considering his almost two years of peaceful presence in Macau-by asking Fr. Miguel dos Anjos, in 1677, for a statement on the case, as well as on the arrest of Louis Chevreuil. At a time when he had already left the office of governor of the bishopric, Fr. Miguel dos Anjos said nothing concerning the Holy Office, stating that he had sent both prisoners to Goa "by very strict orders that I had from the Count of St. Vincent viceroy of India, ordering that I should send him all French clerics and even Bishops that disembarked in this city [Macau], as ordered by his Majesty". ${ }^{88}$ António de Morais Sarmento also avoided any reference to the Holy Office in the declaration to the Provincial of Japan, not referring to Fr. Miguel dos Anjos as commissary of the tribunal, although Filippuci's petition expressly mentioned him in that capacity. In the decades that followed the events, there was thus a concern to avoid a clear association with the Inquisition on the part of all those involved in the arrest of the French missionaries.

This display of prudence wasn't arbitrary, since in 1675 Pierre Lambert de la Motte divulged in Siam the brief Cum ad aures nostras which exempted apostolic missionaries from the jurisdiction of the Inquisition of Goa in territories not subject to the temporal rule of the Portuguese Crown. ${ }^{89}$ Its dissemination in Asia, contrary to what might

86 Chappoulie, Aux origines d'une Église, vol. 1, p. 184; Forest, Les missionnaires français, p. 182.

87 François Pallu, Relation abregée des missions et voyages des Evesques Francois, envoyez aux Royaymes de la Chine, Cochinchine, Tonquin, \& Siam, Paris: Chez Charles Angot, 1668, pp. 118-119.

88 Certificate by Fr. Miguel dos Anjos, OESA, 27 November 1677, Macau. BAL, 49-V19, f. 176: “[...] por ordens que tiue mui apostada [sic, apertada] do senhor conde de são Vicente Viso Rei da Jndia, ordenandome nellas que todos os clerigos francezes e ainda Bispos que aportassem nesta Cidade lhos mandasse, por ser assy ordem de sua magestade".

${ }^{89}$ According to the brief, dated 10 November 1673: "removeamus, Vicarios omnes Apostolicos, eorumque Missionarios jam missos, nec non ad Sinas in Cocincinam, 
have been expected, did not lead the Holy Office to express a real opposition to an initiative that so restricted its jurisdiction. In the words of Sevin, Francisco Delgado e Matos had assumed himself as "Protettore per l'executore delle Bolle della S. Sede". In a reply from François Pallu, bishop of Heliopolis and apostolic vicar of Tonkin, to the priests of the Society of Jesus, he recalled that the inquisitor had also recognized the authority of Lambert de la Motte, to the point of punishing his own commissary, Fr. Luís Fragoso. ${ }^{90}$ It is undeniable that, despite the opposition felt by the apostolic vicars, they saw the Holy Office-or at least one inquisitor in particular-not as a deterring factor, as the priests of the Society of Jesus and the diocesan authorities assigned to the Patronage would have wished, but rather as an element in favor of their enterprise. In 1669, when João de Lima de Abreu, representing the ordinary jurisdiction, was sent as a visitor to Siam with a set of 24 articles against the actions of the apostolic vicars, he alluded to their interference in the affairs of the Inquisition, in that they were "qualifying by opposition, incarcerating, denouncing propositions, or suspicions in faith, which are causes proper to the Holy Office".91 However, the favor granted by the Inquisition to the execution of the brief would strongly limit the possibility of finding in the tribunal an added value in the defense of the rights of Patronage.

Tunchinum, Siamum, Cambojam, aliaque loca orientalia in dies mittendos ab Inquisitionis Goanae jurisdictione in iis regionibus, quae temporali Regis Portugalliae domino non subsunt prorsus immunes declaramus". There is another brief dated from the same day, addressed to the chapter of Goa or the archbishop, exempting the apostolic vicars and their missionaries from their respective jurisdiction. The briefs were published in Jayme Constantino de Freitas Moniz, Corpo diplomatico portuguez, Lisbon: Typographia da Academia Real das Sciencias, 1910, vol. 14, pp. 168-170.

90 "Replica del vescouo d'Eliopoli alla Risposta dei PP. della Compagnia". ASPF, Scritture Riferite nei Congressi, Indie Orientali e Cina, Miscellanea 17, s/f (letter S, § 7).

91 "Cargos que hiço a los señores Obispos Franceses, que residen en Sian, Vn Visitador remitido por el Cauildo de Goa”. ARSI, Jap.-Sin. 76, fl. 138: “[...] calificando por oposiciones, encarzelando, declarando proposiciones, ô sospechosas en la fé, que son causas proprias del santo officio". This document was later sent to Manila, where it was received by the commissary of the Holy Office of that city, who sent it to the Inquisition of Mexico City, which in turn sent it to the Consejo de la Suprema Inquisición in Madrid. 
In Lisbon, the news about the brief Cum ad aures nostras would not be received with the same compliance. Informed of the papal decision, the Conselho Ultramarino consulted the regent D. Pedro about the document, which called into question the Crown's rights. The brief had been conceived in light of the information received about the quarrel between Fragoso and Lambert de la Motte, and the imprisonment of Louis Chevreuil. However, it rested on an understanding that had greater consequences for Portugal, namely that territories such as China, Cochinchina, Tonkin, Siam or Cambodia were not subject to the spiritual rule of the Crown. ${ }^{92}$ The Conselho Ultramarino replied that

"in Cambodia, Siam, Bengal, and other lands where the missionaries reside, Your Highness effectively has Captains and Judges, who administer justice to the Christian vassals who reside in them, and therefore the Holy Office is in perpetual possession of exercising his jurisdiction in them".93

The content of the consultation makes it clear that the jurisdiction of the Holy Office is subsidiary or authorized by conditions verified a priori: missionaries, representatives of justice or government and vassals. It was precisely these criteria that we found in the witness statement taken by Francisco Barreto de Pina in the 'bandel' of Ayutthaya in 1681, mentioned above.

As Giuseppe Marcocci and José Pedro Paiva noted, the convergence between the Inquisition and the Empire was desired in Portugal. ${ }^{94}$ In the Estado da Índia, however, the Holy Office's rapid compliance with the papal determinations could prove an obstacle in that regard. The advent of the apostolic vicars of the Propaganda Fide on the Asian scene had opened up unavoidable channels of dialogue with Portuguese ecclesiastical authorities (the Holy Office amongst them), due to the entrenchment of more than a century and a half of Portuguese interests in the different contexts of missionary intervention, regardless of the greater or lesser formality of the jurisdictional ties that bound them to

92 Consultation of the Conselho Ultramarino with the King of Portugal and his Reply, on 18 and 20 March 1677, Lisbon. ANTT, Tribunal do Santo Ofício, Conselho Geral do Santo Ofício, liv. 102, fl. 16v.

93 Ibidem, fls. 17-17v: "[...] que em Camboja, Sião, Bengala, e outras terras em que residem Missionarios, tem $\mathrm{V}$. A. de facto capitães e ouuidores, que administrão justiça aos vassallos Christãos que nellas residem, e por tanto està o Santo Officio em posse inveterada de exercer nellas sua jurisdição".

94 Marcocci / Paiva, História da inquisição portuguesa, p. 234. 
the Crown of Portugal. The brief of 1673 did not mean an end to this dialogue and adjustment, on the contrary. As early as 1678, the Congregation was already discussing the possibility of extending the exemption from the Holy Office of Goa to the Catholic communities subject to the jurisdiction of the apostolic vicars, ${ }^{95}$ and in 1680 , the inquisitor Francisco Delgado e Matos continued to respond to letters sent by the Propaganda Fide, manifesting what remained a common topic of the missions in Asia: the disaffection with the Society of Jesus. ${ }^{96}$

This, of course, did not prevent Delgado e Matos from voting in favor of a policy of sending official embassies from Goa to the polities of Southeast and East Asia to secure the expulsion of the apostolic vicars in the Junta das Missões' session of April 23, 1683.97 The Junta das Missões was created in 1681, in the aftermath of the Propaganda Fide's rulings of the previous year to expel four Jesuits from the missions of Conchinchina and Tonkin and to impose a vote of obedience to the apostolic vicars on all regular and secular clergy operating in the territories of their vicariates. ${ }^{98}$ The beginning of the Juntas' sessions in

95 "Scrittura Seconda di Monsignor Segretario riferita nella Congregatione particolare della China li 21 Marzo 1678". ASPF, Acta Congregationis Particularis super rebus Sinarum et Indiarum Orientalium (Acta CP), vol. 1B, f. 18.

96 The inquisitor accused the Society of Jesus' missionaries of sowing intrigues and opposing the ordinary jurisdiction, thus effectively jeopardizing missionary efforts. Letter of Francisco Delgado e Matos, inquisitor of Goa, to the cardinals of the Sacred Congregation of Propaganda Fide, November 12, 1680, in Goa. ASPF, SC Indie Orientali, Cina, vol. 2, fls. 783-783, 786-786v. I thank Prof. António Guimarães Pinto for his translation of this letter.

97 Ruling of the Junta das Missões of April 23, 1683, in Panelim. AHU, Conselho Ultramarino, Índia, cx. 58, doc. 95.

98 The Junta das Missões that should gather in Goa was an organism created to rationalize the missionary efforts under the auspices of the Padroado in the face of the increasing competition experienced in the second half of the $17^{\text {th }}$ century. It was comprised by the viceroy, the archbishop, the chairman (senior inquisitor) of the Inquisition of Goa, the chancellor, the overseer of Treasury and the secretary of the State. Other actors could, on occasion, be called to participate and vote in the meetings. When referring to the creation of the Junta, Fr. Francesco Saverio Filippucci wrote that this new "tribunal manages the affairs pertaining to the missions, accepting or excluding the missionaries as they please and it is believed that it will only grow stronger and [will] intervene further on these affairs" ("Questo Tribunale uà di facto maneggiando le cose appartenente alle Missioni, accettando, ò escludendo li Missionarij à suo piacere, e si crede, che 
1681 surely altered the balances of power in Goa, leaving lesser leeway for the more favorable dispositions towards the Roman Congregation displayed by Francisco Delgado e Matos in previous years. On April 28, 1682, an "anti-Congregation" - as reported by the French missionaries in Asia-was held in Goa at the request of the viceroy to address the Propaganda ruling of 1680 . According to the same source, the "entire assembly" agreed on the illegitimacy of the Roman Congregation's actions and that the Portuguese clergy should not profess a vow of obedience to the apostolic vicars. ${ }^{99}$ As head of the Inquisition of Goa, it is expected that Francisco Delgado e Matos would have been summoned as well, in which case he would have been one of the voters against the Propaganda Fide ruling.

The new political environment should help us understand the apparent divergence between these institutional stances and Matos' earlier decisions. This provides a fine example of the difficulties of trying to ascribe political attitudes to institutions or to determine their political behavior. ${ }^{100}$ From the cases mentioned above, it is not possible to support the ingrained notion that the Inquisition of Goa acted unequivocally as a defender of the rights of Patronage against the apostolic vicars and the missionaries under their jurisdiction. ${ }^{101}$ Rather, the expectations and sensitivities of their ministers, the hardening of both the Portuguese Crown and the Holy See's stance on their

s'andara ognigiorno auuantaggiandosi, e impegnandosi in questi negotij"). On the Junta das Missões see Marcia Eliane Alves de Souza e Mello, "As juntas das missões ultramarinas. Gênese e evolução": Amazônia em Cadernos, 7/8 (2001-2002), pp. 11-13. On the 1680 rulings by the Congregation of Propaganda Fide, read Chappoulie, Aux origines d'une Église, vol. 2, pp. 64-65. See also, the letter by Fr. Francesco Saverio Filippucci, SJ, Provincial of Japan, to the Superior General of the Society of Jesus, October 20, 1682, in Macau. ARSI, Jap.-Sin 163, f. 189v.

99 "Annales de la mission des EE. VV. aa. du Tonkin en 1683": Archives des Missions Étrangères de Paris, vol. 665, f. 10-11; Alberts, Conflict and Conversion, p. 41. I would like to express my gratitude to the Archives de Missions Étrangères de Paris for making this document available to me.

100 Ana Isabel López-Salazar Codes, "Puderão mais os inquisidores que o rey. Las relaciones entre el Santo Oficio y la Corona en el Portugal de la Restauración (1640-1668)": Cuadernos de Historia Moderna, 39 (2014), pp. 137-163, online: http://dx.doi.org/10.5209/rev_CHMO.2014.v39.45845 [13-10-2020].

101 See Alberts, Conflict and Conversion, 39-41. 
jurisdictional rights impacted on the attitudes and decisions of the inquisitors at Goa.

As the inquisitorial correspondence of this period between Goa and Lisbon is incomplete, we cannot determine the immediate reaction of the Portuguese Inquisition to the consultation of the Conselho Ultramarino of 1677. The extant documents seem to reflect a greater convergence between the point of view of the royal counsellors and the practices of the Goa Inquisition only after the creation of the Junta das Missões. In a letter of 1688 from the inquisitors, they wrote that "the jurisdiction of this Inquisition extends throughout India". Because of this, they dispatched commissions to the missionaries authorizing them to absolve converts in the internal forum in the "parts where His Majesty has no temporal dominion".102

\section{Final Remarks}

In light of the events that involved Pierre Lambert de la Motte, Pierre Brindeau and Louis Chevreuil between 1666 and 1670, it is clear that the Holy Office played a much less linear role in its relationship with the Propaganda Fide than the isolated case of Fr. Ephraim de Nevers might lead us to believe. Far from being able to look upon the Estado da Índia and its institutions in coherent unity in opposition to the interference of Propaganda, it is important to consider, first of all, the expectations that the papal mobilization had generated among the clergy involved in the Christianization effort under the auspices of the Patronage. The awareness of the financial limitations of the Crown, experienced firsthand by many priests and missionaries involved in the missions of the Estado da Índia, on the one hand; the resentment felt towards the protagonism of the Society of Jesus, on the other; were factors that impacted in a not insignificant way the priests and religious orders at the collective, individual, psychic and emotional levels, besides the objectively material level. The enthusiasm with which several missionaries, priests and-in this case-inquisitors and Inquisition

102 Letter from the inquisitors of Goa to D. Veríssimo de Lencastre, Inquisitor General of Portugal, 22 January, 1688. ANTT, Tribunal do Santo Ofício, Conselho Geral do Santo Ofício, maço 34, doc. 1, s/f: "[...] a Jurisdição desta Jnquisicão se estende por toda a Jndia”; "[...] partes onde Sua Magestade não tem dominio actual". 
officials welcomed the Propaganda Fide, even when the rights of the Patronage might be prejudiced, shows that not all agents of the Crown opposed the presence of the apostolic vicars. In the set of contradictory interests congregated within the Estado da Índia, the Inquisition did not constitute a homogeneous block of adversity to the apostolic vicars. The analysis of a broader chronology reveals instead an array of changing attitudes on the part of those who served the Inquisition that is difficult to reduce to a single institutional behavior. The convergence between the Inquisition and Empire was thus a conjunctural possibility. It was the fruit of the expectations of the imperial agents (missionaries, vicars, clerics) and of their capacity to secure the inquisitorial jurisdiction or the authority of those who represented it. That convergence was, however, denied by the inquisitors themselves when these same expectations were disappointed by what they understood to be the shortcomings of the Patronage (the Crown) or of some of his agents (the Jesuits). Understanding the deeper dimension of the relationship between the Holy Office and the Propaganda Fide will therefore require a greater investment in studying those who represented the tribunalinquisitors, ministers, officers-vis-à-vis the different moments of tension between the authorities of the Estado da Índia and the policies of the Congregation. 